\title{
Influence of pro-angiogenic cytokines on proliferative activity and survival of endothelial cells
}

\section{L.V.Garmanchouk, O.N.Pyaskovskaya ${ }^{1}$, G.I.Solyanik ${ }^{1}$}

\author{
Taras Shevchenko National University of Kyiv \\ 64, Volodymyrska, Kyiv, Ukraine, 01033 \\ ${ }^{1}$ R.E.Kavetsky Institute of Experimental Pathology, Oncology, and Radiobiology \\ 45, Vasylkivska Str., Kyiv, Ukraine, 03022
}

liudmylagarmanchuk@rambler.ru; gis@onconet.kiev.ua

\begin{abstract}
Aim. Tumor angiogenesis in contrast to physiological one is characterized by high level of malignant cell production of pro-angiogenic cytokines, which have different influence on functional activity of endothelial cells. The goal of the study-to carry out a comparative analysis of the influence of a vascular endothelial growth factor (VEGF) and an epidermal growth factor (EGF) on proliferative activity and survival of endothelial cells upon their confluent and exponential growth. Methods. The proliferative activity of endothelial cells was determined by MTT-test and their viability was detected by the trypane blue exclusion test. Results. It was shown that EGF (irrespectively of the level of serum factors) in concentrations higher than $10 \mathrm{ng} / \mathrm{ml}$ activated the proliferative activity of confluent endotheliocytes in a concentration-dependent manner by $18-36 \%(p<0.05)$ as compared to the control, while this cytokine didn't affect the endothelial cells in the exponential growth phase. VEGF in wide concentration range didn't display the mitogenic effect on endotheliocytes in both confluent and exponential growth phases. Furthermore, VEGF in concentrations higher than $100 \mathrm{ng} / \mathrm{ml}$ inhibited proliferative activity of confluent endothelial cells by $12 \%$ $(p<0.05)$. In case of deficiency of nut-rients, EGF and VEGF promoted the survival of endothelial cells, considerably decreasing their death. Conclusions. EGF, in con-trast to VEGF, stimulates proliferation and survival of the endo-thelial cells, whereas VEGF has significant influence only on the survival of the cells.
\end{abstract}

Keywords: epidermal growth factor (EGF), vascular endothelial growth factor, proliferative activity, endothelial cells.

Introduction A number of current investigations have proven the existence of two phases of angiogenesis. The first phase includes activation of endotheliocytes, increase in vascular permeability, degradation of basal membrane, migration and invasion of endothelial cells into extracellular matrix, active proliferation of

(C) Institute of Molecular Biology and Genetics NAS of Ukraine, 2010 endotheliocytes and formation of "lumens"; the second phase is differentiation with the formation of microvascular network [1-3].

The first phase of angiogenesis was simulated in vitro by exponential growth of endotheliocytes and the second one was mimicked by "stationary" (confluent) growth $[2,4,5]$. 

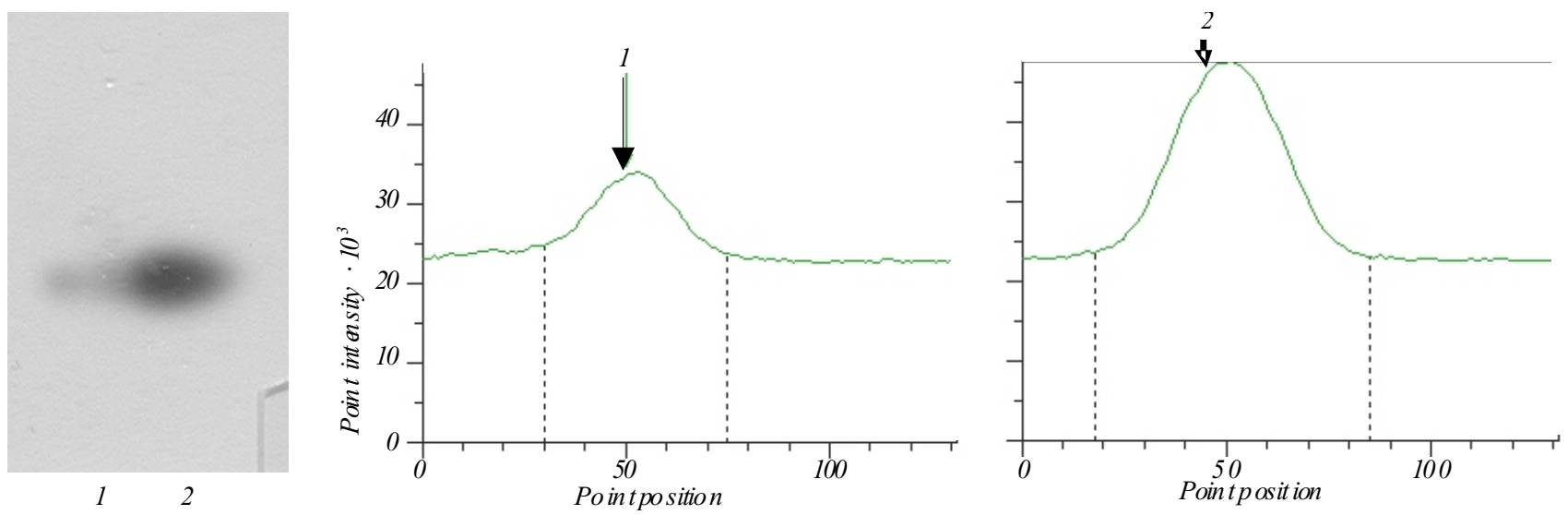

Fig.1 Western-blot analysis of native VEGF (1) (10 $\mu \mathrm{g}$ of total protein per one sample) and recombinant VEGF (10 $\mu \mathrm{g}$ per one sample) (2). Detection was performed using goat anti-VEGF-antibodies (Sigma), visualization was conducted by anti-goat antibodies labelled with horse peroxidase and the system of photo-sensitive reagents ECL (Amersham).

Proliferation, migration, and differentiation of endothelial cells are mediated by many specific pro-angiogenic cytokines. The determination of their activity, the production of which by tumour cells under neoangiogenesis is very high contrary to that under physiological angiogenesis, could offer tools to study the mechanism of action of specific agents or to pathways of therapeutic correction of their effect $[4,6$, 7].

Taking the above mentioned into consideration, the aim of this research was to perform a comparative analysis of the influence of main pro-angiogenic cytokines EGF and VEGF (decode) on proliferative activity and viability of endothelial cells in the confluent and exponential growth phase, as well as at the condition of deficiency of serum factors in growth medium.

The tasks of investigation were as follows: isolation and purification of native EGF and VEGF, maintenance of exponential and confluent growth of endothelial cells in vitro; determination of the influence of cytokines on proliferative activity of endotheliocytes in a wide range of concentrations; comparison of the cytokines effect on proliferative activity of endothelial cells depending on the time of incubation with EGF and VEGF and in the absence of serum in growth medium.

Materials and Methods VEGF (Sigma, USA), goat polyclonal antibodies against VEGF (Sigma), heparin-sepharose (Amersham, USA), polyclonal rabbit anti-goat immunoglobulins labelled with horse peroxidase (Dako Cytomation, USA), MTT (tetrazolium blue) and trypane blue (Sigma) were used in the work.

Cell lines and conditions of cultivation. MAEC (endothelial cells from aorta of mice [8]) were incubated in DMEM medium (Sigma) with addition of $10 \%$ fetal bovine serum (FBS) (Sigma) and at non-serum conditions. The incubation time for endothelial cells was 3-96 hours at $100 \%$ humidity, $t=37^{\circ} \mathrm{C}$, and $5 \% \mathrm{CO}_{2}$.

Purification of native EGF and VEGF. Native EGF from submandibular glands of non-linear male mice was purified by the method, previously proposed by us, using mini-columns Sep-Pak $C_{18}$ [9]. The EGF preparation was of high purity (95\% of total protein) and attached to specific receptors on the cells of A-431 line (the data are not presented).

The cells of LLC/R9 subline were used as a producent of mouse VEGF as the data of immuno-enzyme assay, performed with the mouse VEGF kit (R\&D, England), testify to a high level of producing this cytokine by the cells [10]. VEGF was purified by two-stage chromatography considering the basic physical and chemical features of cytokine, namely, $\mathrm{pI}=8.5$ and high affinity to heparin [11].

After liophilisation the peptide was identified using Western-blot analysis with recombinant mouse VEGF (Sigma) and goat polyclonal anti-VEGF antibodies (Sigma) (Fig.1). As seen, the molecular mass of VEGF, purified by us, is identical to the recombinant VEGF (Sigma). According to the protein amount, calculated 

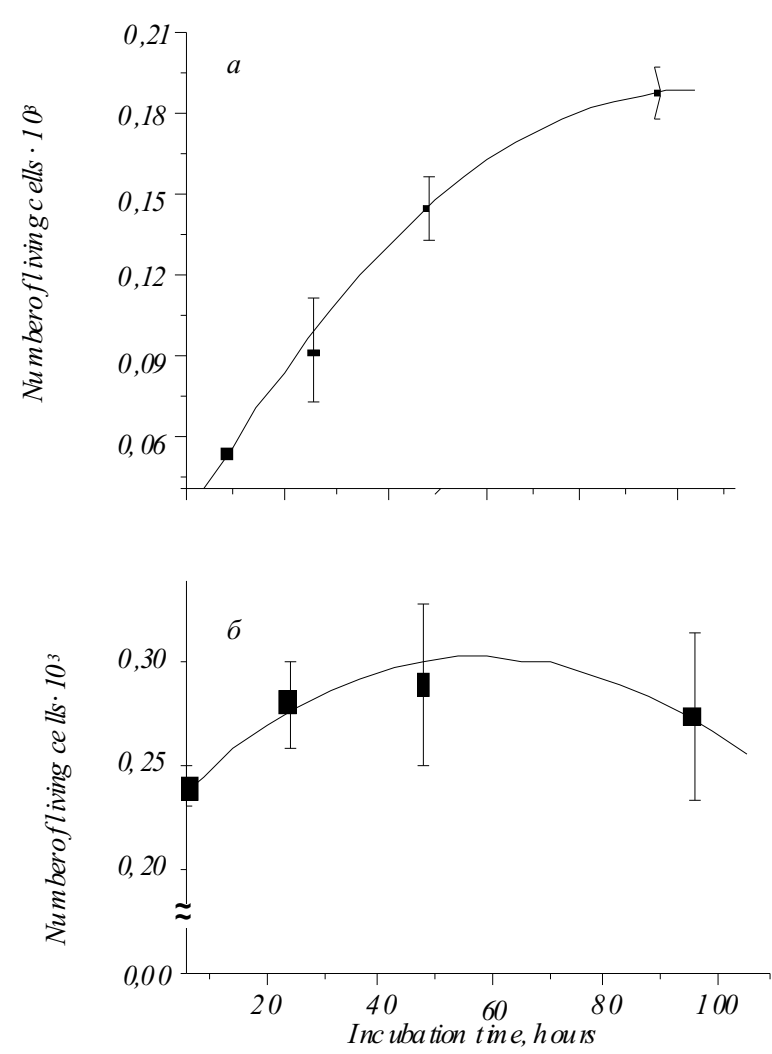

Fig. 2 Growth kinetics of MAECs (6-96 hours) at conditions of their seeding with initial density of $5 \times 103(a)$ and $25 \times 103$ cells per well (b)

similarly to the recombinant VEGF (Fig.1), the amount of peptide, obtained by us, was $1 \mu \mathrm{g}$ per $3.6 \mu \mathrm{g}$ of total protein in eluate. This index was considered for calculating the concentration of native VEGF while determining its biological activity.

The investigation of influence of EGF and VEGF on proliferative activity of endothelial cells. Proliferative activity of endothelial cells was determined by MTT-test [12] calculating the number of living cells per well ( units of $540 \mathrm{~nm}$ extinction ) as well as by routine calculation of the cells in hemocytometer using trypane blue. The data, obtained by the first procedure, were presented in percents of the corresponding control taken as $100 \%$. To study the influence of cytokines on proliferative activity of endothelial cells in "stationary" (confluent) and exponential growth phases, the cell seeding densities were experimentally determined. The previous data $[7$, 13] and results of experimental study show the following optimal concentrations: $5 \times 103$ cells per well of 96-well plate - in the exponential growth phase, almost 4 days; $25 \times 103$ cells per well - in the confluent growth phase (Fig.2). To analyse the mitogenic effect of EGF and VEGF, they were used in a wide range of concentrations added to the cells in the confluent growth phase during two days of incubation. To determine the influence of EGF and VEGF on the viability of endothelial cells, they were studied in the concentration of $10 \mathrm{ng} / \mathrm{ml}$ at the exponential growth in a standard growth medium with $10 \%$ FBS and in non-serum medium.

The results were statistically processed by parametric and non-parametric methods using Origin 6.0 software package.

Results and Discussion The effect of EGF and VEGF on proliferative activity of endothelial cells was found to depend significantly on the growth phase. The screening of mitogenic effect of EGF and VEGF on endothelial cells in the confluent growth phase was performed in a wide range of the factors concentration (1-1000 ng/ml). After 24-hour incubation of cells with cytokines EGF showed the mitogenic effect on confluent cells at these concentrations. This effect was also proven by the increase in a number of living cells per well by $17-35 \%(\mathrm{p}<0.05)$ compared to the control (Table 1). The increase in the mitogenic effect was observed with the increase in EGF concentration. This correlates with the data of other authors [14] who proved that proliferative activity of endothelial cardiac cells of rats at monolayer growth with $10 \%$ serum increases by almost 1.5 times at the addition of EGF in the concentration range of $0.1-100 \mathrm{ng} / \mathrm{ml}$; the maximum effect was observed at the cytokine concentration of $5 \mathrm{ng} / \mathrm{ml}$. No significant influence of VEGF on proliferative activity of endotheliocytes in the concentration range of $1.0-5.0 \mathrm{ng} / \mathrm{ml}$ was observed. An insignificant, but statistically valid decrease in the number of endotheliocytes by $12 \%(\mathrm{p}<0.05)$ at the VEGF concentrations of $100.0-1,000.0 \mathrm{ng} / \mathrm{ml}$ was revealed. It was not due to the cytotoxic influence of cytokine, as the number of dead cells did not exceed $5-10 \%$ of their total number and did not differ considerably from the control. Inconsiderable inhibition of endotheliocytes proliferation (cytostatic effect), caused by VEGF after 24 hours, may be explained by the reverse regulation of the cells specific 
Table 1

Influence of EGF and VEGF on proliferative activity and survival of endothelial cells in confluent growth phase (cell incubation time with cytokines -24 hours)

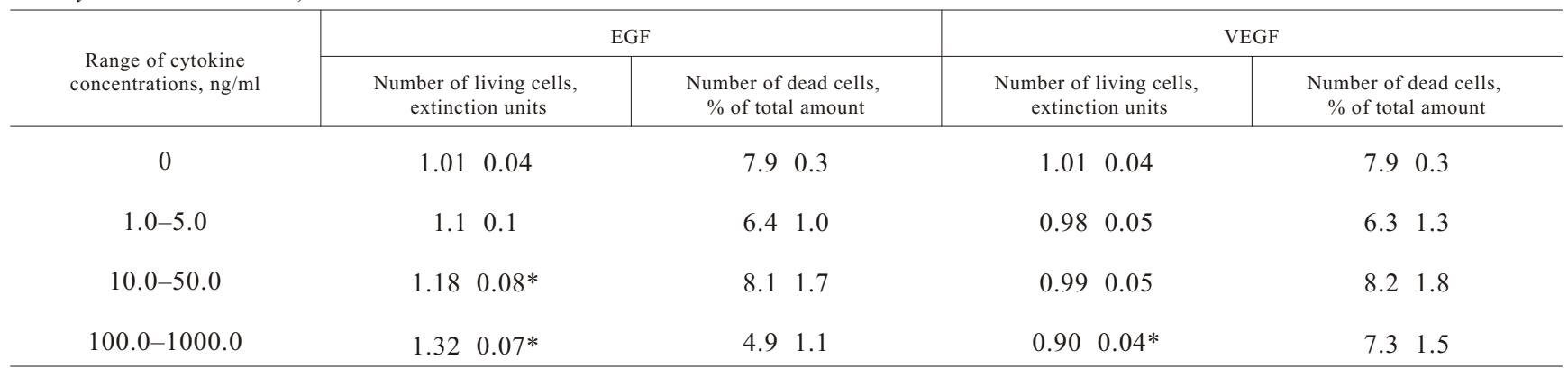

$\mathrm{N}$ o t e. Valid difference $(\mathrm{p}>0.05)$ from respective control is marked in Tables $1-3$ with an asterix.

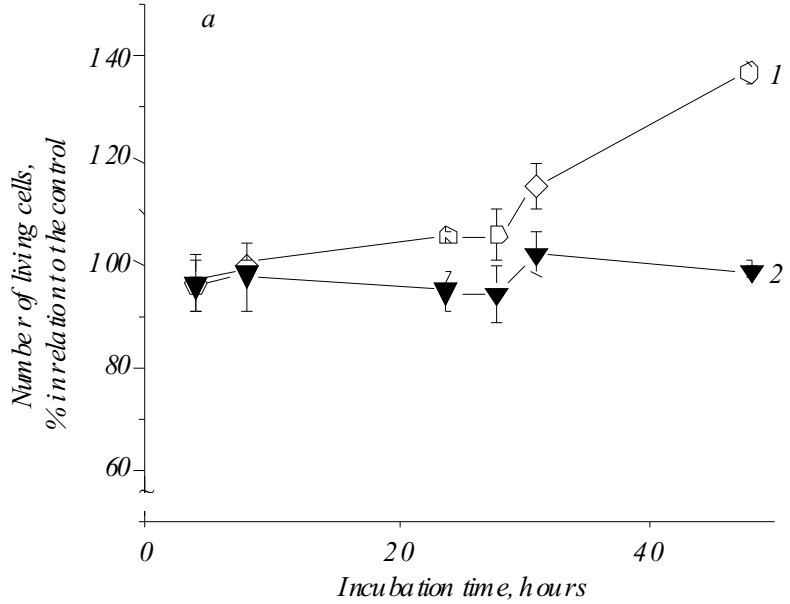

Fig.3 Influence of EGF (1) and VEGF (2) (concentration $10 \mathrm{ng} / \mathrm{ml}$ ) on proliferative activity of endothelial cells in their confluent (a) and exponential $(b)$ growth phases. Incubation of cells at standard conditions with $10 \%$ FBS during $0-48$ hours.

receptors under the influence of high concentration of definite cytokine.

The prolongation of incubation with pro-angiogenic cytokines up to two days caused an increase of the EGF mitogenic effect on the cells in the confluent growth phase. For instance, the 48-hour influence of EGF in the concentration of $10 \mathrm{ng} / \mathrm{ml}$ resulted in increasing amount of living cells per well by $36.5 \pm 1.5 \%(\mathrm{p}<0.05)$ compared to the respective control (Fig.3), while there was no registered stimulating effect of the corresponding VEGF concentration on proliferation of endotheliocytes.

As for the growth of cells in exponential phase, neither of growth factors showed stimulating or inhibiting effect at incubation with cells in adequate nutrient medium, containing 10\% FBS (Fig.3, b).

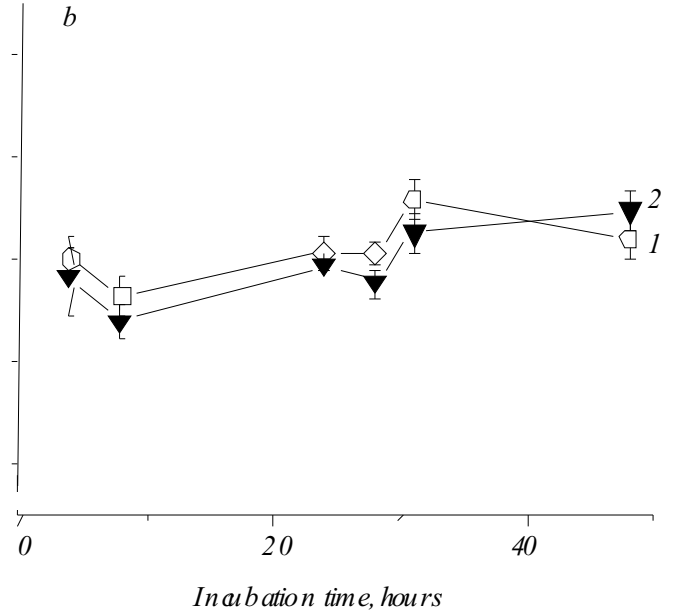

There was also neither increase nor decrease in the viability index of endothelial cells in exponential growth phase under the influence of EGF and VEGF (the data are not presented).

The investigation of the cytokine influence at serum factors deficiency demonstrated that EGF and VEGF had different effect on proliferative activity of endotheliocytes (Fig.4, $a, b$ ). The data presented show (Fig.4, a) that the influence of VEGF in the concentration of $10 \mathrm{ng} / \mathrm{ml}$ on proliferative activity of endothelial cells was insignificant at different cell seeding density. Contrary to VEGF, the influence of EGF results in the increase in endothelium proliferative activity: on the first day of incubation there was only a tendency to the activation of cell proliferation at all cell seeding densities, while on the second day we revealed 

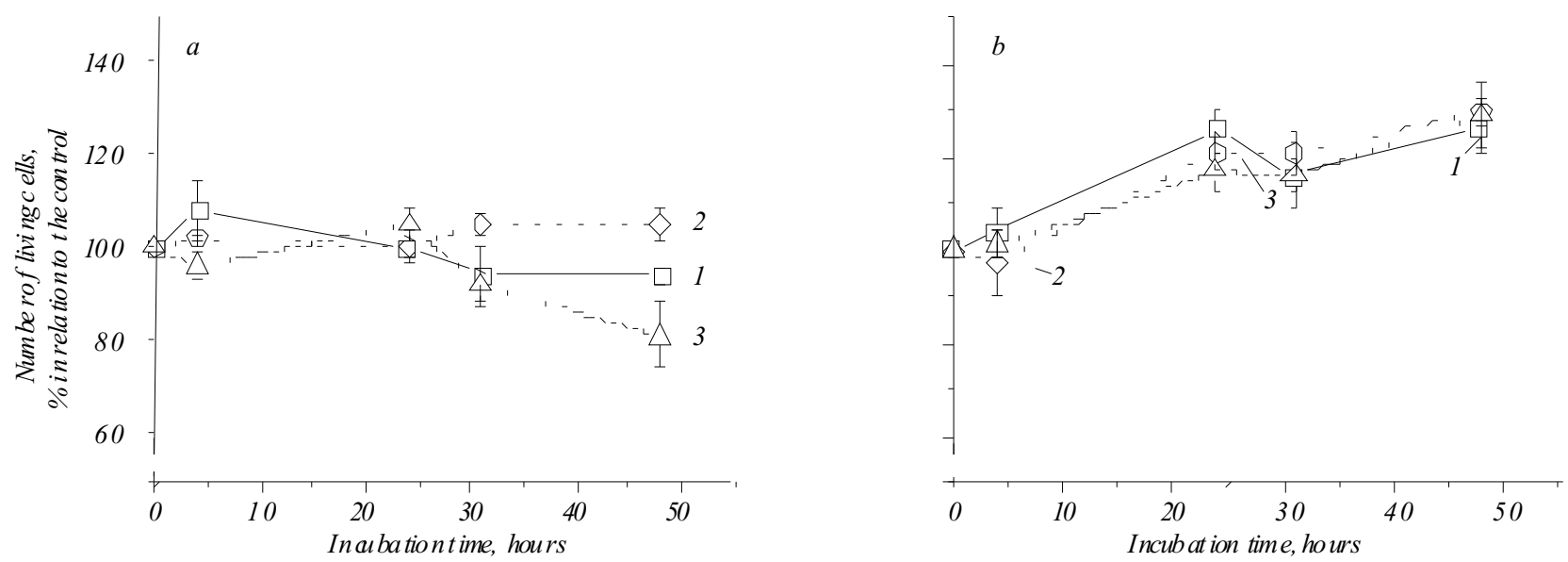

Fig.4 Influence of VEGF $(a)$ and EGF $(b)$ in the concentration of $10 \mathrm{ng} / \mathrm{ml}$ on proliferative activity of endothelial cells at their incubation in non-serum medium. The cells were sown with different initial density $\left(10 \times 10^{3}(1), 25 \times 10^{3}(2), 50 \times 10^{3}(3)\right.$ cells per well) and incubated with cytokine for 4-48 hours.

at high cell concentrations ( 50x103 cells per well) a valid increase in the number of living cells almost by $30 \%(\mathrm{p}<0.05)$ (Fig.4, $b)$.

It is noteworthy that in control experiments, i.e. cell incubation in non-serum nutrient medium without any introduction of cytokines, there was demonstrated a progressive increase in the percentage of dead cells which was $36 \%$ on average by the end of the second day $(\mathrm{p}<0.05)$ compared to $7 \%$ of dead cells at the initial seeding.

Both EGF and VEGF cause significant decrease in the percentage of dead cells by $70 \%(\mathrm{p}<0.05)$ after two days of incubation, thus promoting survival of endothelial cells at deficiency of growth factors and nutrients (Table 2, 3).

Therefore, the results obtained testify to the mitogenic effect of EGF on endothelial cells in the confluent growth phase in both adequate cultural medium and non-serum medium, as well as to the valid increase in the index of cell viability, caused by EGF. On the contrary, VEGF does not show any mitogenic effect in regards to endotheliocytes, though it is also the factor, promoting survival of cells.

Therefore, the results obtained by us on the effect of EGF and VEGF on actively proliferating endothelial cells and endotheliocytes in the confluent growth phase evidence that the mentioned cytokines influence different phases of angiogenesis. Considering that EGF in vitro demonstrates mitogenic effect on cells in the confluent growth phase and at serum factor deficiency, it may influence in vivo the involvement of endothelial cells of blood vessels into tumour angiogenesis and induce the proliferation of endotheliocytes, while VEGF is a factor, stimulating the formation of lumens and new vessels.

There are proofs that inhibition of the EGF-receptor of endothelial cells in the confluent growth phase results in lower VEGF secretion which is the basis of inhibition of the endothelial cells morphogenesis [15]. Hence, in our case the activation of endothelial cells proliferation in monolayer under the influence of EGF and triggering a signalling cascade via EGF-receptor may also be partially determined by higher secretion of the main pro-angiogenic cytokine - VEGF. The fact that both cytokines cause a decrease in the number of dead cells at serum factors deficiency testifies to their capability of promoting the endothelial cells survival which is in good agreement with the published data $[15,16]$.

Recently there have been a large number of investigations on the stimulation of proliferation of endothelial cells by the growth factors $[4,14,17]$ and on the inhibition of proliferation of endothelial cells as main targets of anti-tumour angiogenesis-mediated therapy $[6,18,19]$.

Conclusions This work has revealed that EGF demonstrates the mitogenic effect on endothelial cells in the confluent growth phase in both adequate cultural medium and non-serum medium; however, EGF does not influence the mitogenic activity of endotheliocytes 


\section{Table 2}

Influence of VEGF on survival of endotheliocytes (estimated by the number of dead cells per well in \% of total amount) at their incubation in non-serum medium

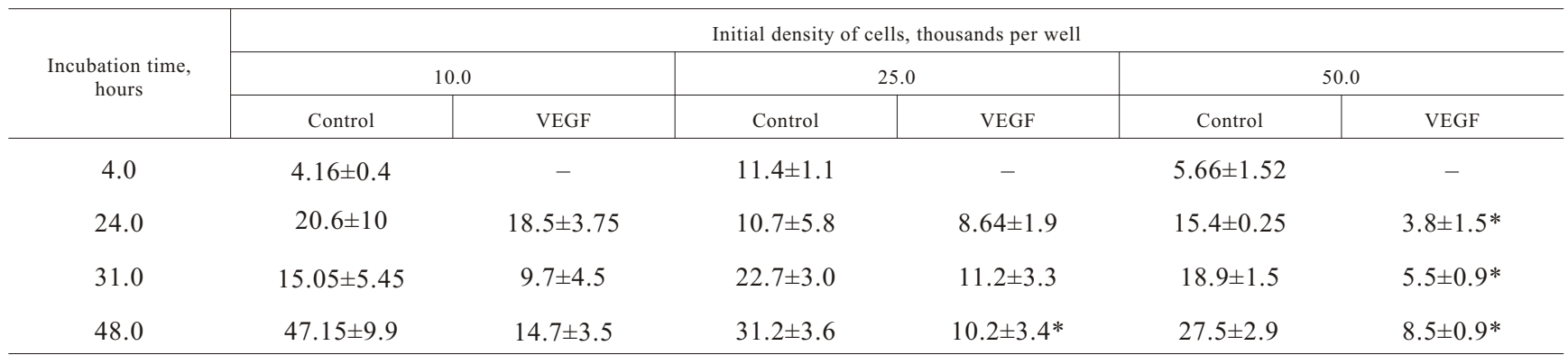

Table 3

Influence of EGF on survival of endotheliocytes (estimated by the number of dead cells per well in \% of total amount) at their incubation in non-serum medium

\begin{tabular}{|c|c|c|c|c|c|c|}
\hline \multirow{2}{*}{$\begin{array}{c}\text { Incubation time, } \\
\text { hours }\end{array}$} & \multicolumn{6}{|c|}{ Initial density of cells, thousands per well } \\
\hline & Control & EGF & Control & EGF & Control & EGF \\
\hline 4.0 & $4.16 \pm 0.4$ & - & $11.4 \pm 1.1$ & - & $5.66 \pm 1.52$ & - \\
\hline 24.0 & $20.6 \pm 10$ & $11.68 \pm 0.38$ & $10.7 \pm 5.8$ & $4.0 \pm 0.4$ & $15.4 \pm 0.25$ & $7.5 \pm 1.7 *$ \\
\hline 48.0 & $47.15 \pm 9.9$ & $7.7 \pm 0.8^{*}$ & $31.2 \pm 3.6$ & $8.1 \pm 2.3 *$ & $27.5 \pm 2.9$ & $7.7 \pm 1.9^{*}$ \\
\hline
\end{tabular}

in the exponential growth phase. Contrary to EGF, no mitogenic activity of VEGF has been revealed. Both cytokines promote the survival of endothelial cells growing at serum factors deficiency.

The work was partially financed by the grant of the Ministry of Science and Education, No. DP/66, dated April 27, 2004 "Neovascularization of malignant tumours as a target for selection of anti-tumour preparations with anti-angiogenic activity" and in the framework of target programme "Specificities of functioning of oncogenome".

The authors would like to express their gratitude to Dr.T.Tagenbratt from Stockholm Cancer Centre for kindly presented endothelial cells and consultative help with their cultivation.

\section{Л. В. Гарманчук, О. М. Пясковська, Г. І. Соляник}

Вплив проангіогенних цитокінів на проліферативну активність та виживання ендотеліальних клітин

Резюме

Пухлинний ангіогенез на відміну від фізіологічного характеризується високим рівнем продукування пухлинними клітинами проангіогенних цитокінів, які по-різному діють на функиіональну активність ендотеліальних клітин. Мета роботи - провести порівняльний аналіз впливу фактора росту ендотеліальних клітин (VEGF) та епідермального фактора росту (EGF) на проліферативну активність і виживання ендотеліальних клітин за їхнього експоненційного та конфлюентного росту. Методи. Проліферативну активність $i$ виживання ендотеліальних клітин лінї̈ MAEC під впливом EGF ma VEGF визначали за МTT-тестом $і$ підрахунком живих клітин з використанням трипанового синього. Результати. EGF (незалежно від рівня сироваткових факторів) у концентраціях, більших за 10 нг/мл, активує проліферативну активність ендотеліоиитів за умов конфлюентного росту на $18-36 \%(p<0,05)$ ефективніше порівняно з контролем, тод $i$ як при експоненційному рості ендотеліоцитів суттєвого впливу зазначеного ичитокіну на проліферацію клітин не виявлено. VEGF у широкому діапазоні концентрацій не проявляє мітогенного ефекту на ендотеліоцити за умов як конфлюентного, так і експоненційного росту. Більше того, у концентраціях, вищих за 100 нг/мл, VEGF на $12 \%(p<0,05)$ інгібує проліферативну активність ендотеліальних клітин в умовах конфлюентного росту. У разі дефіциту сироваткових факторів обидва ицитокіни сприяють виживанню ендотеліальних клітин, суттєво зменшуючи їхню загибель. Висновки. EGF на відміну від VEGF стимулює як проліферацію ендотеліальних клітин, так $і$ їхнє виживання, тоді як VEGF сприяє лише виживанню ендотеліоцитів.

Ключові слова: епідермальний фактор росту (EGF), фактор росту ендотеліальних клітин (VEGF), проліферативна активність, ендотеліальні клітини з аорти мишей лінії МАЕС. 


\section{Л. В. Гарманчук, О. Н. Пясковськая, Г. И. Соляник}

Влияние проангиогенных цитокинов на пролиферативную активность и выживаемость эндотелиальных клеток

Резюме

Опухолевый ангиогенез в отличие от физиологического характеризуется высоким уровнем продуцирования опухолевыми клетками проангиогенных циитокинов, по-разному влияющих на функииональную активность эндотелиальных клеток. Цель работы - провести сравнительный анализ действия фактора роста эндотелиальных клеток (VEGF) и эпидермального фактора роста (EGF) на пролиферативную активность и выживаемость эндотелиальных клеток при их конфлюэнтном $u$ экспоненииальном росте. Методы. Пролиферативную активность и выживаемость эндотелиальных клеток линии МАЕС при влиянии EGF и VEGF определяли МTT-тестом и подсчетом живых клеток с использованием трипанового синего. Результатыл. EGF (независимо от уровня сывороточных факторов) в концентрациях выше 10 нг/мл активирует пролиферативную активность на конфлюэнтной стадии роста эндотелиоцичтов на $18-36 \%(p<0,05)$ эффективнее по сравнению $c$ контролем, тогда как при экспоненциальном росте эндотелиоиитов существенного влияния этого ичитокина на пролиферацию клеток зафиксировано не было. VEGF в широком диапазоне концентраций не проявляет митогенного эффекта на эндотелиоииты при их конфлюэнтном и экспоненциальном росте. Более того, в концентрациях выше 100 нг/мл VEGF на $12 \%(p<0,05)$ ингибирует пролиферативную активность эндотелиальных клеток при конфлюэнтном росте. В случае дефицита сывороточных факторов оба циттокина способствуют выживанию эндотелиальных клеток, существенно уменьшая их гибель. Выводы. EGF в отличие от VEGF стимулирует как пролиферацию эндотелиальных клеток, так и их выживаемость, тогда как VEGF способствует только выживаемости эндотелиоцитов.

Ключевые слова: эпидермальный фактор роста (EGF), фактор роста эндотелиальных клеток (VEGF), пролиферативная активность, эндотелиальные клетки из аорты мылии линии $M A E C$.

\section{REFERENCES}

1. Risau W. Differentiation of endothelium // FASED J.-1995.9, N 10.-P. 926-933.

2. Pauly R. R., Passaniti A., Crow M., Kinsella J. L., Papadopoulos N. Monticone R., Lakatta E. G., Martin G. R. Experimental models that mimic the differentiation and dedifferentiation of vascular cells // Circullation.-1992.-86, N 6.-P. III. 68-III.73.

3. Folkman J., D'amore P. A. Blood vessel formation: What is its molecular basis? // Cell.-1996.-87, N 7.-P. 1153-1155.

4. Joyce N. C., Zhu C. C. Human corneal endothelial cell proliferation: potential for use in regenerative medicine // Cornea.-2004.-23, N 8, Suppl.-P. S8-S19.

5. Terramani T. T., Eton D., Bui P. A., Wang Y., Weaver F. A., $Y u$ H. Human macrovascular endothelial cells: optimization of culture conditions // In Vitro Cell Develop. Biol. Anim.2000.-36, N 2.-P. 125-132.

6. Chen C., Li J., Micko C. J., Pierce G. F., Cunningham M. R., Lumsden A. B. Cytotoxic effects of basic FGF and heparin binding EGF conjugated with cytotoxin saporin on vascular cell cultures // J. Surg. Res.-1998.-75, N 1.-P. 35-41.

7. Garmanchouk L. V., Pyaskovskaya O. N., Yanish Yu. V., Shlyakhovenko V. A., Dasyukevich O. I., Solyanik G. I. Influence of aconitine-containing herbal extract $\mathrm{BC} 1$ on proliferative and electrokinetic characteristics of endothelial cells // Exp. Oncol.-2005.-27, N 4.-P. 262-266.

8. Gumcovski F., Kaminska G., Kaminski M., Morrisey L. W., Auerbach $R$. Heterogeneity of mouse vascular endothelium. In vitro studies of lymphatic, large blood vessel and microvascular endothelial cells. // Blood Vessels.-1987.-24, N 12.-P. 11-23.

9. Ivashchenko Yu. D., Gout I. T, Garmanchuk L. V., Osipova $L$. A. Purification of the epidermal growth factor with used HPLC // Exp. Oncol.-1985.-7, N 3.-C. 46-49.

10. Solyanik G. I., Pyaskovskaya O. N., Garmanchouk L. V. Cisplatin-resistant Lewis lung carcinoma cells possess increased level of VEGF secretion // Exp. Oncol.-2003.-25, N 4.P. 260-265.

11. Alistratov A. V., Lisniyak I. A., Yatsenko S. M., Vinnitsky V. B. The dependence of VEGF level from characteristics of 3LL carcinoma development in C57B16 mice // Exp. Oncol.2002.-24, N 1.-P. 64-68.

12. Mosmann T. Rapid colorimetric assay for cellular growth and survival: application to proliferation and cytotoxic assayas // J. Immunol. Meth.-1983.-65, N 1-2.-P. 55-63.

13. GarmanchukL. V., Pyaskovskaya O. N., Vovyanko S. I., Plyushch G. I., Solyanik G. I. Vascular endothelial growth factor-prerogative of the actively proliferating endothelial cells // IX Ukrainian biochemical conference (Kharkiv, 24-26 October, 2006).-Kharkiv, 2006.-P. 88.

14. Mooradian D. L., Diglio C. A. Effects of epidermal growth factor and transforming growth factor-beta 1 on rat heart endothelial cell anchorage-dependent and -independent growth // Exp. Cell Res.-1990.-186, N 1.-P. 122-129.

15. Semino C. E., Kamm R. D., Lauffenburger D. A. Autocrine EGF receptor activation mediates endothelial cell migration and vascular morphogenesis induced by VEGF under interstitial flow // Exp. Cell Res.-2006.-312.-N 3.-P. 289-298.

16. Suhardja A., Hoffman $H$. Role of growth factors and their receptors in proliferation of microvascular endothelial cells // Microsc. Res. Technol.-2003.-60, N 1.-P. 70-75.

17. Tamama K., Fan V. H., Griffith L. G., Blair H. C., Wells A. Epidermal growth factor as a candidate for ex vivo expansion of bone marrow-derived mesenchymal stem cells // Stem Cells.-2006.-24, N 3.-P. 686-695.

18. Sini P., Wyder L., Schnell C., O'Reilly T., Littlewood A., Brandt R., Hynes N. E., Wood J. The antitumor and antiangiogenic activity of vascular endothelial growth factor receptor inhibition is potentiated by ErbB1 blockade // Clin. Cancer Res.-2005.-11, N 12.-P. 4521-4532.

19. Kerbel R., Folkman J. Clinical translation of angiogenesis inhibitors // Nat. Rev. Cancer.-2002.-2, N 10.-P. 727-739.
UDC 576.535

Received 13.01.09 